\title{
The impact of shopping centre development on informal and small businesses in Lagos, Nigeria
}

\author{
M S Ikadeh \\ C E Cloete \\ Department of Construction Economics \\ University of Pretoria, South Africa
}

\section{Keywords}

Retailing, shopping mall, informal traders, formal businesses, small businesses, Nigeria

\begin{abstract}
Purpose of the research: This study investigated the impact of formal shopping centre development on informal and small businesses in Lagos, Nigeria.

Methodology: Semi-structured interviews with the business owners as well as shoppers were conducted. The population size included 15 informal and 15 small business equally distributed between five different shopping areas including the areas around the two major shopping centres in Lagos. Interviews were also done with a hundred shoppers around these two centres. The collected data were analysed using content analysis method.

Findings: Most of the informal and small businesses are struggling to survive. Different strategies have, however, been developed for competing against the giant retailers in the shopping malls. The different types of goods sold in shopping centres and in informal traders were characterised and the reasons for the support of these respective businesses were identified.

Practical implications and Conclusions: While the development of shopping centres may be of benefit to the community it serves, the valuable role of informal trading in developing countries should not be ignored.
\end{abstract}

Corresponding author: C E Cloete

Email addresses for the corresponding author: chris.cloete@up.ac.za

First submission received: $5^{\text {th }}$ January 2020

Revised submission received: $12^{\text {th }}$ May 2020

Accepted: 21st May 2020

\section{Introduction}

Prior to 2005, there were only a handful of shopping centres in Nigeria, all smaller than $3048 \mathrm{~m}^{2}$ $\left(10,000 \mathrm{ft}^{2}\right)$. In 2019 Nigeria boasted of more than 18 shopping centres larger than $3048 \mathrm{~m}^{2}\left(10,000 \mathrm{ft}^{2}\right)$. This development has changed the landscape of several cities in Nigeria. The retail market in Nigeria is gradually moving towards a more formal and organised arrangement. The development of formal shopping centres in Nigeria had a major impact on existing small and informal businesses. The informal business is a popular part of the Nigerian economy and is thoroughly embedded in the trading and retailing activities of the Nigerian economy. Most of the Nigerian cities are characterised by these informal businesses and trading activities. The informal markets and small businesses are very lucrative in Nigeria and this has contributed socially and economically to the livelihood of those that are involved in it.

The objectives of this research were to determine the effect of formal shopping centre development on informal and small businesses in Nigeria. This was done by, firstly, investigating how formal retailing has affected the income and livelihood of informal and small businesses in the areas where shopping centres had been developed and, secondly, how the informal and small businesses responded to the pressure being exerted by the big retailers.

\section{Literature review}

Nigeria has one of the largest informal sectors in Africa (CBN 2009). Salisu (2001) estimated the informal economy to be about 9.64 percent to 65.43 percent of the GDP in the period from 1960 to 1997 . He concluded that the size of the informal sector in 1997 was about 58.76\% of the GDP. Schneider (2002:18) 
estimated the size of Nigeria's informal sector to be $57 \%$ of its gross national product (GNP) which is equivalent to US\$212, 6 billion. Oduh et al. (2008:8) stated that "the informal economy in Nigeria remains a thing of wonder, as it has never been comprehensively analysed and evaluated. Many questions remain unanswered about the dynamics, cause and size of the informal sector in Nigeria". $t$ is generally accepted that the informal sector refers to activities which are outside the domain of regulated economic activities (Koto 2015; Amin 1992). The informal sector develops in parallel with modern formal markets and is central to rural and urban food security, livelihood generation, and job creation (Vorley 2013). The typical characteristics of the formal and informal sectors have been compared by Cole and Fayissa (1991:780).

Schneider (2007) conducted estimates of the informal economies of 146 countries around the world. The study revealed that the size of the informal economy from 2004 to 2005 in Nigeria was around 59.5\% of the "official" GDP. Oduh et al. (2008:10) calculated the size and the cause of informal sector in Nigeria from 1970 to 2005. Data from 4,455 informal sector enterprises revealed that the size of the informal sector has fluctuated between 44 and $73 \%$ of the GDP during that period. It also showed that the drivers of the informal sector in Nigeria are declining income, a high tax burden, a high black-market premium and a high regulation of the economy.

The Nigerian economy is still developing, with small-scale retail trades forming the bulk of the economic activity for the majority of the populace. Therefore, markets are especially important and essential and as such cannot be ignored. Vagale (1972:8) states that "the relevance of the market is not only for its role in the economic life of rural and urban communities, but also as a social entity. Through the years, markets acquired this distinctive social-cultural value".

When unemployment is on the rise, many people turn to informal retail activities as a source of income (Terblanche, 1998). Retailing activities seem to be the most attractive among different types of occupational patterns available, retailing has an easy entry point for the immigrant group, and it provides an opportunity of self-employment with minimal capital investment and minimal technical constraints (Paddison, et.al., 1990).

Most of these factors contribute to the growth of informal hawking activities around the urban centres. The spatial changes in the formal sector reflects the penetration of western consumer values; whilst the informal sector represents a potential solution to unemployment in developing countries.

The relationship between formal and informal traders is summarised by Paddison (1990): “...less developed countries retail outlets with western characteristics seem to coexist uneasily alongside informal traders. Generally, 'place specific' retail development in different developing context appears to be more integrated with their urban context by accommodating formal and informal retail functions within a shopping development; meanwhile, the imported ideas from the west fails to ensure an interactive retail environment as they tend to accommodate a specific economic class of retailers and consumer, hence, physically isolate themselves from a specific urban context".

Formal retailing activity in Nigeria has flourished recently, especially from the second decade of the twenty-first century. The main player in the formal retailing in Nigeria is the South African retail giant Shoprite. The entry of this large formal retail chain and the development of ultra-modern shopping malls has changed the landscape of retailing in Nigeria forever.

\section{Research methodology}

The study adopted qualitative analysis and data was collected from informal business owners, small business owners, and shoppers.

The interviews were conducted face to face using structured interview guideline with open-ended questions. The purpose of the research is to analyse and understand the impact of shopping mall development on informal retailing and small businesses, their response to the competition, their decisionmaking behaviours, and the probable co-existence of formal and informal retailing.

The study area chosen for this study is Lagos. Lagos, with a population of about 17 million people, is the most populous city in Nigeria and has one of the largest and most dynamic informal economies in the world (Neuwirth 2009: 409). It has been estimated that around 50\%-75\% of the workforce of Lagos are employed informally (LSG 2004). The informal economy in Lagos therefore provides livelihoods for some millions of people. However, in an attempt to modernise the city, the state government adopted a zero- 
tolerance policy to street trading in 2008, which led to the displacement of street traders located around the inner-city market in Lagos.

Since Lagos is divided into the mainland and the island, the study area was chosen to be the area around the Ikeja City mall on the mainland and the area around the Palms Shopping Mall in Lekki Peninsula to the east of the city, thereby covering the two major axis of Lagos. The Palms Shopping Mall $\left(19,520 \mathrm{~m}^{2}\right)$ was opened on 6 March 2006 with 69 stores. It was the first of its kind in the state and was celebrated throughout the state. The shopping mall introduced the populace to organised and formal retailing, shopping for products and services under one roof. Ikeja City Mall, opened on 14 December 2011 with about 90 stores and service points, is a two-floor development spanning 23,000 $\mathrm{m}^{2}$.

The population size includes 15 informal and 15 small business distributed equally between the areas Opebi, Toyin Street, Allen Avenue, Lekki, and Ajah (three of each type). These included the areas around The Palms (Lekki) and Ikeja City Mall. The research followed a semi-structured approach. This approach provided flexibility in making sure that when relevant comments were made through the interview, they could be noted under general comments. Open-ended questions were asked since the research was qualitative in nature. The questions had been pre-tested by interviewing three informal traders and three small business owners who provided meaningful feedback and that was used to update the final version of the interview guideline.

The shopper respondents were chosen around the major areas close to the malls. Fifty questionnaires were administered in Ikeja and 50 questionnaires were also administered in Lekki. There will not be an in-depth analysis of this data as this is not the focus of the study. Quota sampling was used in this research because of a lack of a comprehensive list of all formal and small businesses around the study area. By using this method, the different subgroups in the selected population would be represented on pertinent sample characteristics to the extent that the researcher deemed suitable (Zikmund 2003). The data-gathering tool used was an in-depth, semi-structured interview guideline with open-ended questions. All the informal traders and the small business owners were interviewed face-toface. An arrangement was made before the interview date for convenience.

The interview duration was less than one hour on average. Data were recorded during interviews using a note pad or questionnaire forms. Some of the major concepts were read back to the interviewee to ensure accurate data were recorded. The collected data were analysed using content analysis method (Welman and Kruger, 2001) and are presented in a tabular format. The interview responses were analysed so as to identify components for each interview question. The components that were the same were grouped together. The number of times the component occurs was therefore counted and recorded.

\section{Findings}

Ownership of the businesses were split more or less equally between men and women. Seventy percent of the owners were between 31 and 50 years old and sixty to seventy percent of businesses have been in operation for longer than 5 years.

The purpose of the first interview question was to understand the impact of shopping mall on business owners.

The shopping malls were perceived to have had both positive and negative impact on the small businesses and the informal businesses. Nevertheless, findings show that more than $65 \%$ of the businesses suffered negative impact since the development and the subsequent opening of the shopping malls. Most businesses that perceived a negative impact from the opening of the shopping mall, cited cheaper products in the shops in the mall and the newness of the mall as one of the factors of attraction. The novelty factor may fade, but with several other malls springing up every year, this may persist for a long time.

In conclusion, most of the small business and informal business around Ikeja City Mall and the Palms Mall in Lekki have a perception that these malls impact their business negatively. 
Table 1: The impact of the malls on both informal and small businesses

\begin{tabular}{|l|c|c|}
\hline \multicolumn{1}{|c|}{ Answer } & Frequency & Percentage \\
\hline Positively impacted & 3 & 5 \\
\hline Negatively impacted & 20 & 15 \\
\hline Not affected & 7 & 70 \\
\hline Reasons for Positive Impact & 8 & 30 \\
\hline \multicolumn{1}{|c|}{ Profit increased since the mall opened } & 7 & \\
\hline Tmprovement in social facilities, e.g. road & & 35 \\
\hline Products are cheaper at the mall & 12 & 25 \\
\hline The popularity of the mall & 7 & 5 \\
\hline The newness of the mall & 4 & 15 \\
\hline Wider range of merchandise at the mall & 3 & 10 \\
\hline Easy access to the mall & 3 & 10 \\
\hline Profit margin did not drop or increase & 3 & 20 \\
\hline Orocation is not close to the mall & 5 & 10 \\
\hline
\end{tabular}

The impact of the malls on both informal and small businesses is indicated in table 1, while the effects of the development of the shopping mall on the profitability of the business are summarised in table 2.

Table 2. Impact of shopping centre on profitability of business

\begin{tabular}{|c|c|c|c|c|}
\hline & \multicolumn{2}{|c|}{ Small Business } & \multicolumn{2}{|c|}{ Informal Business } \\
\hline & Frequency & Percentage & Frequency & Percentage \\
\hline Decreased & 10 & 70 & 8 & 70 \\
\hline Increased & 5 & 30 & 3 & 20 \\
\hline Remained unchanged & 0 & 0 & 4 & 10 \\
\hline \multicolumn{5}{|l|}{ Answer - Increase in Profit } \\
\hline$\%$ Increase interval & Frequency & Percentage & Frequency & Percentage \\
\hline $20-40$ & 0 & 0 & 0 & 0 \\
\hline $41-60$ & 1 & 10 & 1 & 10 \\
\hline $61-80$ & 1 & 10 & 1 & 10 \\
\hline $81-100$ & 1 & 10 & 1 & 10 \\
\hline$>100$ & 0 & 0 & 0 & 10 \\
\hline \multicolumn{5}{|l|}{ Answer - Decrease in Profit } \\
\hline$\%$ Decrease interval & Frequency & Percentage & Frequency & Percentage \\
\hline $20-40$ & 3 & 30 & 3 & 30 \\
\hline $41-60$ & 2 & 20 & 3 & 30 \\
\hline $61-80$ & 3 & 30 & 2 & 20 \\
\hline $81-100$ & 2 & 20 & 2 & 20 \\
\hline
\end{tabular}


Seventy percent of the respondents of the small business group reported a decrease in monthly profit while 30\% reported an increase in profit level of the business. However, 80 percent of the informal business reported a decline in profit while $10 \%$ reported an increase in profit level of the business. It is apparent that the informal businesses are more negatively affected by the shopping malls.

The small businesses offer a larger and wider variety of products than the informal businesses and also have the capacity to sell in bulk, while the informal businesses sell mostly loose products (figure 1). It was also observed during the research that most of the informal businesses sell mostly non-food items and this contributed to a greater percentage of the business turnover. The respondents were also requested to indicate the products that were affected the most as a result of the opening of the shopping malls. About $75 \%$ of informal business owners indicated that since the opening of the malls, a noticeable decrease was experienced in the sale of juice, soaps and detergent and beverages, while $70 \%$ of the small business owners indicated that the sales of rice, fresh chicken and beverages were lower than before (figure 2).

$\square$ Small Business $\square$ Informal Business

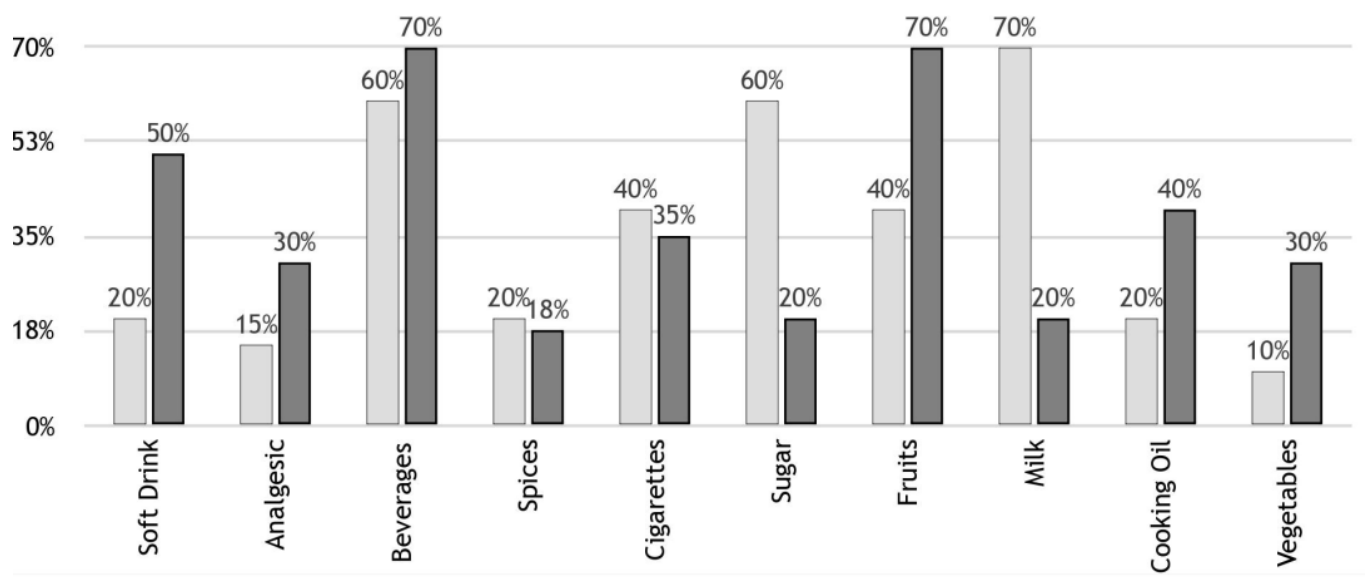

Figure 1. Products contributing most to the turnover of informal and small businesses.

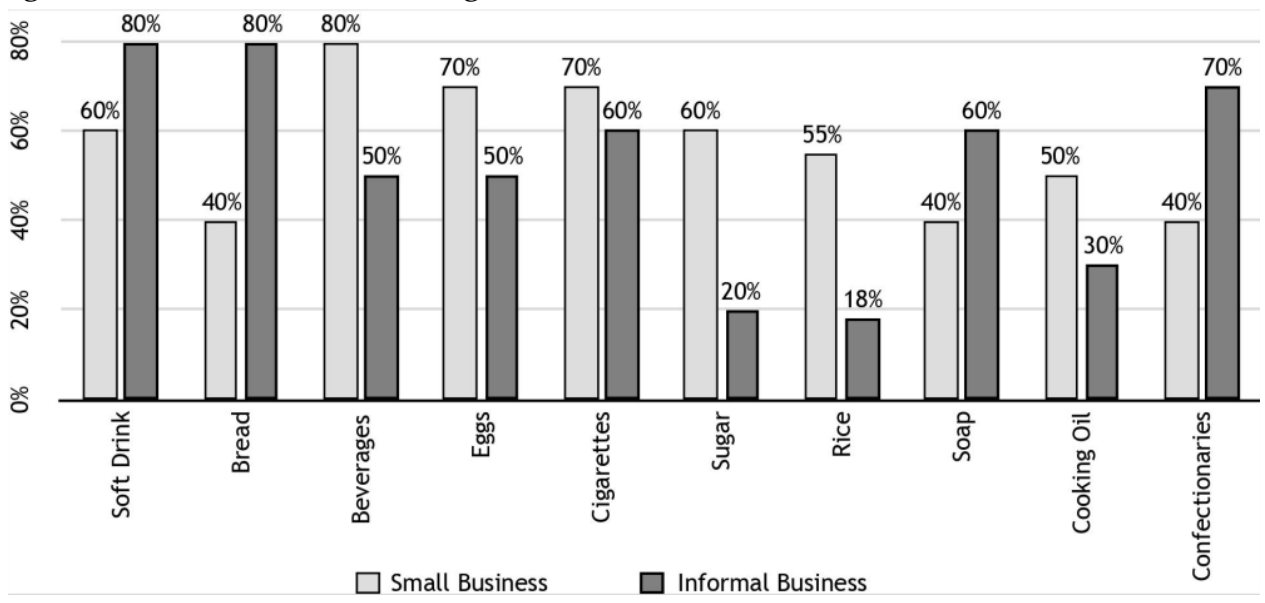

Figure 2. Products Experiencing Decline in Sale

The perception of the business owners regarding the survival of businesses was also analysed. Seventy percent of the business owners reported that there was a decrease in other businesses in the area, 
$20 \%$ of the business owners reported an increase while $10 \%$ reported that the businesses in their area has not changed (table 3 ).

The reasons offered were varied. More than $60 \%$ of the respondents reported a decrease due to the opening of the Ikeja City Mall and the Palms Mall. The contribution of poor business management to the decrease was reported by $10 \%$ of the group and $20 \%$ of the respondents reported a lack of confidence to compete with the larger retailing shops in the malls. However, $10 \%$ of the respondents reported an increase. This was attributed to the high unemployment level in the country.

Table 3. Impact of shopping centre on survival of businesses

\begin{tabular}{|r|c|c|}
\hline \multicolumn{1}{|l|}{ Answer } & Frequency & Percentage \\
\hline Decreased & 18 & 70 \\
\hline Increased & 2 & 20 \\
\hline Reasons for Decrease & 1 & 10 \\
\hline Due to opening of Ikeja City Mall and the Palms Mall & 4 & \multicolumn{1}{|c|}{ Percentage } \\
\hline Shops at the malls sell cheaper & 3 & 30 \\
\hline Poor management & 1 & 10 \\
\hline More people go to the malls because of novelty & 1 & 10 \\
\hline
\end{tabular}

The small businesses and the informal retailers responded somewhat differently to competition from the large retailers in the shopping malls (table 4).

More than $50 \%$ of the respondents reacted to the pressure by opening for longer hours and selling household essentials, as most of the customers may need just a bar of soap or milk for which purchase, they cannot go to the mall. Most of the businesses are competing in one way or the other to the pressure from the larger retailers, but it was also noted that despite this most of the businesses are still struggling.

\begin{tabular}{|r|c|c|}
\hline \multicolumn{1}{|c|}{ Responses } & Frequency & Percentage \\
\hline From Small Businesses & & \\
\hline Open for longer hours & 4 & 40 \\
\hline More bulk buying and selling at a cheaper rate & 2 & 20 \\
\hline Product customisation & 1 & 10 \\
\hline Introduction of credit buying to the customer & 1 & 10 \\
\hline Improving the presentation and merchandise mix & 3 & 30 \\
\hline From informal businesses & 3 & 60 \\
\hline Introduction of music and movies on the television & 3 & 30 \\
\hline More household daily needs are sold & 6 & 30 \\
\hline Sell more ethnic products like palm oil, cassava blend (garri) & 3 & 40 \\
\hline Introducing printing and photocopying in the shop & 4 & 20 \\
\hline Maintaining a cleaner environment and better lighting & 2 & 40 \\
\hline Selling more confectionary products for children's demand & 4 & 30 \\
\hline Allowing customers to buy on credit & 3 & 30 \\
\hline
\end{tabular}

Table 4. Defensive responses by informal retailers 
The last question was what informal traders regarded as the probability for the co-existence of the informal retailers and the formal retailers. The significance of this question is to have a perception of level of pressure that is being exerted on the small and informal retailers by the giant retailers in the shopping malls. Sixty percent of the informal retailers were of the opinion that informal retailers and the formal retailers could co-exist, but only $40 \%$ of the small businesses shared that opinion.

The responses from the 100 shoppers who had been interviewed, indicated their shopping frequency (figure 3), the grocery items purchased more frequently from the shopping centres and from informal and small businesses (figure 4 and 5, respectively), the relative support for the shopping centres and the informal and small traders, as well as reasons for that support (figure 6) and whether and why shopping centres had impacted on their lifestyle (figure 7). The most important reasons for purchasing the indicated items from the malls were given as the availability of international brands and a wide range of varieties.
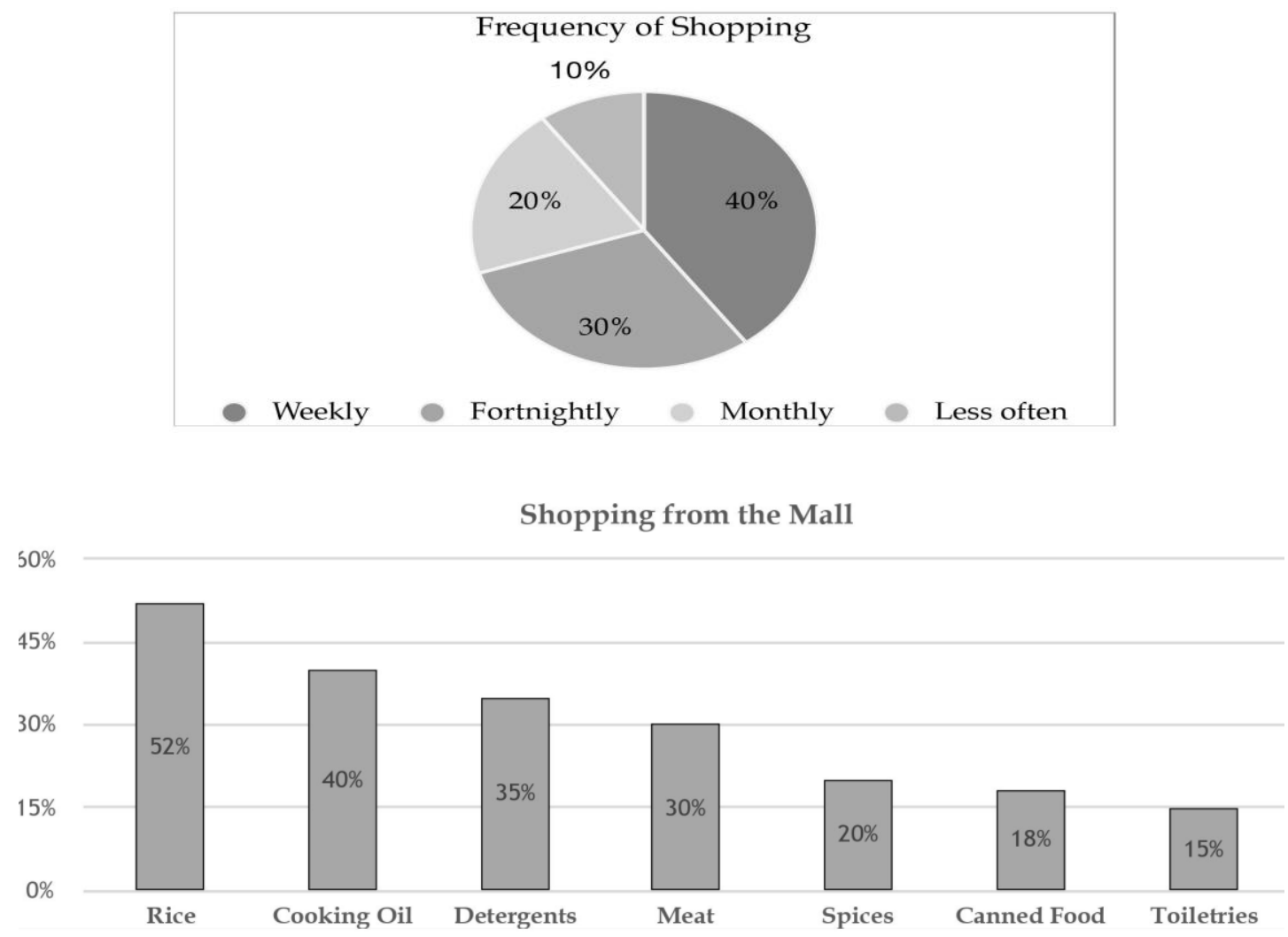

Figure 3. Frequency of shopping

Figure 4. Items purchased more frequently from the mall

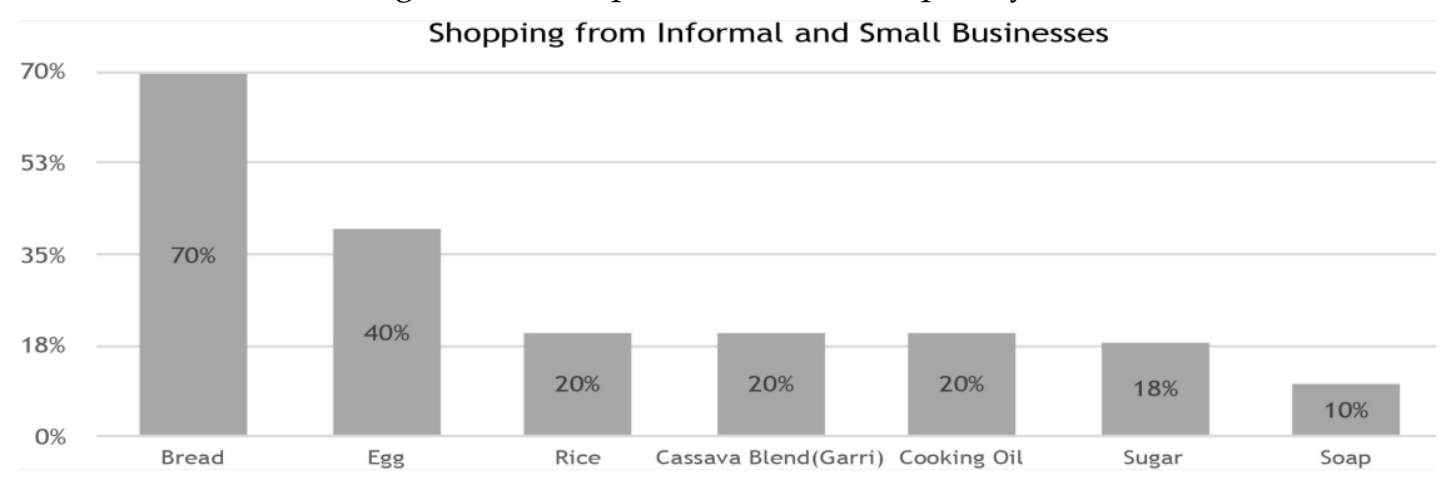


Figure 5. Items purchased more frequently from the small and informal traders

The major reason given for buying the specific items from the informal traders is proximity, as most of these informal retailers are closer to residential location than the malls. In addition to proximity, most of the respondents that shop more at informal retailers do so because of the long-time relationship that has been established with the owners of the informal retailing shops.

On the other hand, the group of respondents that shop more at a mall claimed that there are more international brands available at the shops in the mall, well-organised merchandise, and a wider variety of product. Impact of Shopping Mall on

Lifestyle

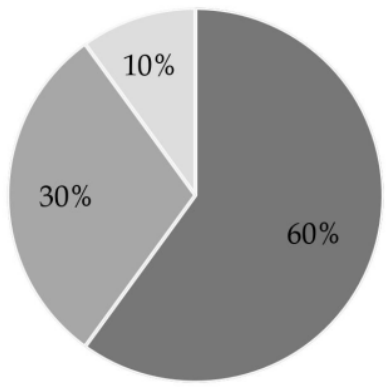

Impacted Not Impacted Indifferent

Figure 6. Relative popularity of shopping malls and informal traders

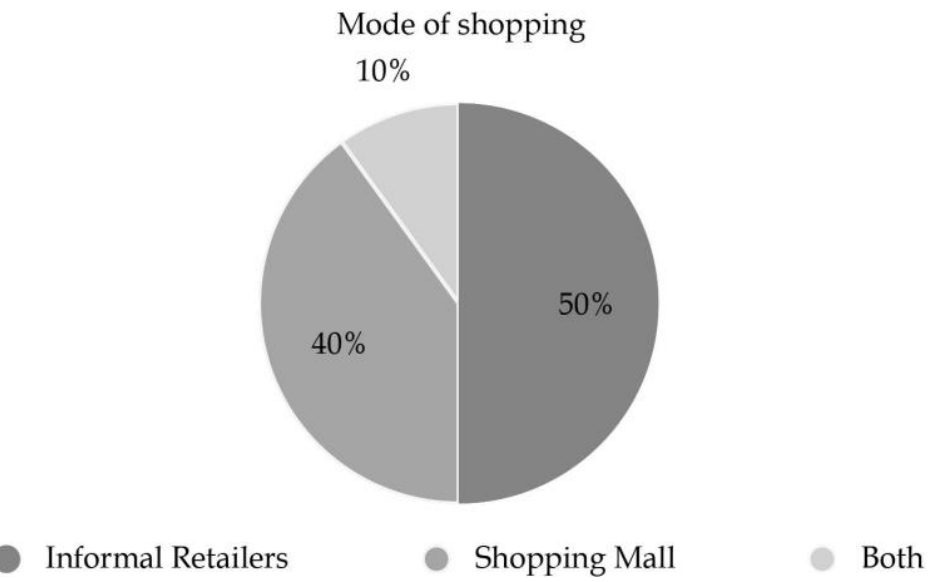

Figure 7. Impact of opening of shopping malls on lifestyle

Most of the respondents reported that the mall has an impact because it has a variety of products and it is convenient to shop there because of parking and kids and adult entertainment area. Some of the respondents also reported cleanliness and proper organisation as a pull factor to the mall. The common denominator is the fact that the mall is a one-stop shop.

\section{Conclusions}

The objective of this study was to analyse the impact of the shopping mall development on the informal and small businesses in Nigeria, and also to evaluate some of the responses of these informal businesses to the pressure that is being exerted by the formal retailers in the shopping malls.

The findings show that more than $65 \%$ of the businesses were impacted negatively since the development and the subsequent opening of the shopping malls. This is in agreement with, among others, Shanmuganandavadivel (2016), who also found an adverse impact on the growth and progress of informal traders in few types of business activities. 
The responses of the informal businesses and the small businesses to the threat of shopping centres varied. Peterson \& McGee (2000) recommended that small businesses or retailers should engage in activities like increasing promotional efforts, pruning products, and adding new products to lower the competition from the larger retailers. The present research indicated that a number of these strategies were also employed by the informal businesses and the small businesses. The strategies that were employed included opening for longer hours, bulk buying and discounts for large purchases, product customisation, introduction of credit to customers, improving presentation and the merchandise mix, adding new products, maintaining a cleaner environment and providing better customer service

It is clear that the informal and small businesses are an integral part of the Nigerian economy and as such cannot be relegated to the background. It is equally clear that development of shopping malls is normally of great benefit to the economic landscape of any community. The ease of shopping and the fact that shopping and other services are located under one roof are factors that cannot be overlooked. Nevertheless, this should not erode the traditional way of shopping that fosters great relationship and that is a source of livelihood to a large percentage of the country's population.

Government should therefore create an environment that will allow the informal retailers to compete favourably with the larger retailers. Red tape should be minimised to enable informal business owners and small business owners to carry out their businesses without undue restrictions. This recommendation is in agreement with that of Koto (2015), who investigated the determinants of the probability that an informal enterprise will have linkages with formal sector. He concluded that the challenge to policy makers in Ghana is to find the right balance between policies that reduces the costs of participating in the informal sector, while increasing the benefits for participating in the formal economy. A similar recommendation was made by Peprah et al, (2019), who recommend the incorporation of activities of informal sector workers into spatial planning, and by Shanmuganandavadivel (2016), who suggests that policy makers should give adequate importance to the views of small retailers while taking the policy decision.

\section{Limitations and directions for future research}

The study focused on Lagos. It is likely that the conclusions are valid in other cities in developing countries as well. This study focused only on fast moving products. There are therefore still a lot of areas to be explored by researchers. Products like clothing and textile, electronics which are locally produced and imported by local merchants should also be researched, so as to evaluate the effect that the entry of clothing giants like Mr. Price, Pep and Game will have on them.

\section{References}

Amin, A.T.M. N. (1992). Urban Planning in Metropolitan Areas of Asia: The Challenges of Accommodating the Informal sector. The Southeast Asian journal of tropical medicine and public health 23 Suppl 3:119-29

CBN (Central Bank of Nigeria). (2009). Annual Report and Statement of Accounts for the Year ended 31st December 2009. Abuja: CBN, pp. liv-lvi.

Chau. K.W. \& Pretorius, F. (2002). Retailers' Location Preferences: The Influence of Time, Micro-spatial and Property Characteristics in a High-Density Urban Area. Discussion paper series. The University of Hong Kong, Hong Kong.

Cohen, B. (2004). Urban growth in developing countries: a review of current trends and a caution regarding existing forecasts. World Development 1(1): 23-51.

Cole, W.E. and Fayissa, B. (1991). 'The urban subsistence labour force: toward a policy-oriented and empirically accessible taxonomy,' World Development 19: 7 (780), Elsevier.

D'Andrea, G. \& Lopez-Aleman, B. (2006). Why small retailers endure in Latin America. International Journal of Retail and Distribution Management 36(9): 661-673.

Koto, P.S. (2015). An empirical analysis of the informal sector in Ghana. The Journal of Developing Areas 49(2): 93-107. Available from: https://www.researchgate.net/publication/269279535_An_Empirical_Analysis_of_the_Informal_Sector_ in_Ghana [accessed May 12, 2020].

Litz, R. \& Stewart, A. (1997). Lilliputian strategies: small business responses to big business entry. Journal of Business and Entrepreneurship 9(1): 59-70.

McGee, J.E. (1996). When Wal-Mart comes down to town: a look at how local merchants respond to retailing giant's arrival. Journal of Business and Entrepreneurship 8(1): 43-52. 
Paddison, R., Findlay, A. M., \& Dawson, J. A. (1990). Retailing in less-developed countries. Retailing environments in developing countries, 3-15.

Oduh, M., Eboh, E., Ichoku, H. \& Ujah, O. (2008). Measurement and explanation of informal sector of the Nigerian economy. African Institute for Applied Economics, Research Paper 3, pp. 1-64.

Peprah, V., Buor, D., Forkuor, D., \& Sánchez-Moral, S. (2019). Characteristics of informal sector activities and challenges faced by women in Kumasi Metropolis, Ghana. Cogent Social Sciences, 5(1), 1656383.

Salisu, M. (2001). Incentive structure, civil service efficiency and the hidden economy in Nigeria. World Bank Institute for Development Economic Research, Discussion Paper No. 2001/86.

Schneider, F. (2002). Shadow Economy. Linz: Johannes Kepler University, pp. 225.

Schneider, Friedrich (2007), "Reducing the Shadow Economy in Germany: A Blessing or a Curse?" Discussion Paper, Department of Economics, University of Linz, Linz.

Schneider, F. \& Enste, D.H. (2000). Shadow economies: size, causes, and consequences. Journal of Economic Literature 38(1): 77-114.

Schneider, F. \& Enste, D.H. (2004). The Shadow Economy: An International Survey. United Kingdom: Cambridge University Press.

Shanmuganandavadivel, J. (2016). A study on the impact of mega shopping malls on small retail business sector. International Journal of Advanced Research 4(8), 1569-1573.

Terblanche, N.S. (1998). Retail Management. South Africa: International Thomson Publishing Southern Africa.

Tustin, D.H. (2004). Consumer spending patterns in the informal retail trade sector of South Africa. South African Business Review Journal 8(3): 26-37.

Vagale L. R. (1972). “An Anatomy of Traditional Markets in Nigeria: Focus on Ibadan City. "(Ibadan, The Polytechnic, 1972): 1-26.

Vorley, Bill (2013). Meeting small-scale farmers in their markets: understanding and improving the institutions and governance of informal agri-foods trade, IIED/HIVOS/Mainumby, London/The Hague/La Paz.

Welman, J. \& Kruger, S. (2001). Research Methodology for Business and Administrative Sciences. 2nd edition. pp. 7, 46-47. Oxford: Oxford University Press.

Zikmund, W.G. (2003). Business Research Methods. 7th edition. Mason: Thomson. 